\title{
The Effect of Economic Growth, FDI, and Educational Rate on IFRS Implementation
}

\author{
Panji Putranto ${ }^{1}$, Sumiyati ${ }^{2}$, Huda Aulia Rahman ${ }^{3}$ \\ \{Panji.putranto@mercubuana.ac.id ${ }^{1}$, sumi.widi@gmail.com² ${ }^{2}$, hudaauliarahman@gmail.com ${ }^{3}$ \} \\ Mercu Buana University, Jakarta, Indonesia ${ }^{1}$, Mercu Buana University, Jakarta, Indonesia ${ }^{2}$, Mercu \\ Buana University, Jakarta, Indonesia ${ }^{3}$
}

\begin{abstract}
The objective of this study was to specify the effect of Economic Growth, Foreign Direct Investment, and Educational Rate on IFRS implementation. Data obtained from the World Bank website. The object of the research is 147 countries were selected using the method of random purposive sampling. This study takes logistic regression analysis data processing with the assistance of SPSS version 25 software. The results consist are that Economic Growth has a positive effect on IFRS Implementation, while Foreign Direct Investment and Educational Rate had no effect on IFRS implementation.
\end{abstract}

Keywords: Economical Growth, Foreign Direct Investment, Educational Rate, IFRS

\section{Introduction}

Every company, especially companies that go public, are required to present financial information in the form of financial reports. The financial statements that are presented consist of statements of financial position, income statements, changes in equity, cash flow reports, and notes to financial statements.

Each country has its own accounting standards as a procedure for processing good financial reports. 2 accounting standards that are generally used as a reference for each country are US Generally Accepted Accounting Principles (GAAP) and International Financial Reporting Standards (IFRS).

The implementation of IFRS was initiated by the European Union in June 2000. The European Union requires that from 2005 go public companies in Europe must set financial reports based on IFRS (1). The IFRS system has not been implemented globally; therefore several countries have not implemented this system, including the United States. Based on the official IFRS website, currently 144 out of 166 countries have fully implemented IFRS.

One of the factors that might affect a country in implementing IFRS is economic growth. Research conducted by (3) and (1) found that the country's economic development had a positive effect on IFRS implementation.

The next factor that may contribute to a country's decision to implement IFRS is Foreign Direct Investment (FDI). The quality of financial information is a main element in the progress and efficiency of capital markets. The main defiance to implementing IFRS lies in the protection of capital market activities, so that the interests of both local and foreign investors will be protected (2).

Another factor that may influence the country's decision to implement IFRS is the degree of public education. The level of understanding about IFRS affects whether a country wants to adopt these standards or not, because these standards are complex. Professional judgment and 
accountant competence can only be obtained through high education levels. Countries with low levels of education will find it hard to understand IFRS and implement it (3).

There is a research gap on the results of previous studies, likewise the importance of the benefits of IFRS implementation witch will be explained further makes the author choose this theme. The difference with previous research is on the number of independent variables, samples and the state as research objects.

The object of this study was to specify the effect of economic growth, Foreign Direct Investment, and the level of education on the implementation of IFRS in countries around the world.

\section{Literature Review}

\subsection{International Financial Reporting Standard's (IFRS)}

To make sure high quality financial reporting, accountants present financial reports in accordance with accounting standards issued by standard-setting institutions. Currently, there are two institutions accounting standard setters major - International Accounting Standards Board (IASB) and Financial Accounting Standards Board (FASB). More than 130 countries follow a standard called International Financial Reporting Standards (IFRS). IFRS was made by the IASB. The IASB is headquartered in London, with 15 members from around the world (4).

IFRS is a standard that adheres to "principles-based", while US GAAP is a standard that adheres to "rules-based" (5). The use of IFRS as an accounting standard is expected to increase the quality of accounting information. The use of a balance sheet approach and fair value in IFRS is expected to reduce accounting fraud (6).

\subsection{Economic growth}

Economic growth occurs when a country broaden its production facilities, improves its public infrastructure, pays attention to educational conditions, and adopts new technology (Sullivan, et al, 2018). GDP growth in a country is the most critical aspect of a country's economic performance a. Since the first, case this is the only way to raise the economic level of the country (7).

GDP measures the production of goods and services in a country. GDP describe the economic capacity of the people of a country (11). GDP is the most common indicator of a country's economic size, although it is widely recognized that GDP disregard several considerations, such as the value of free time and environmental damage that occurs during the country's development process (7).

Based on the above explanation:

\section{H1: Economic growth affects the country in implementing IFRS.}

\subsection{Foreign Direct Investment (FDI)}

FDI is the purchase of physical assets such as real estate or businesses by foreign companies or individuals (8). DFI regarded as supporting uta ma economic growth, especially in developing countries. The importance of FDI can be seen through the channel of technology transfer, new skills, knowledge and techniques in the company's production processes, increasing competition between production for local and foreign producers, exports and imports and economic growth (9). 
There is a relationship between FDI and IFRS. The first reason is that the application of IFRS removes barriers to the comparison of financial information between countries and reduces information asymmetry between local and foreign investors. The second reason is that IFRS has features that investors need, compared to other accounting standards. IFRS emphasizes a more detailed explanation of accounting records, which encourages transparency and will be relevant for investors to make investment decisions (1).

Based on the above explanation:

H2: Foreign Direct Investment influences the country in implementing IFRS.

\subsection{Educational Rate}

The material developed by IAS generally comes from suggestions and opinions of professional competencies as well as practical experiences from various IASB members. In fact, these standards are quite complex and require extensive knowledge to understand them (2).

Countries with education systems that are less well might regard the transition to IFRS is more expensive to implement than other countries with a better education system. Therefore, the level of education affects the country's decision to adopt IFRS (10).

Based on the above explanation:

H3: Educational rate affects the country in implementing IFRS.

\section{Methods}

This research is a research that uses a quantitative approach. The analysis technique used is logistic regression analysis to determine the factors that influence countries around the world to fully implement IFRS. The application used to process data is SPSS version 25.

This study uses data sourced from the world bank website (https://www.worldbank.org) and the IFRS website (https://www.ifrs.org). The research object used was 147 countries. The research object is determined based on the availability of complete information about the variables used. The research object that has been eliminated is the object of research with incomplete information either on the world bank website or the IFRS website.

The logistic regression equation in this study is as follows:

\section{Results and Discussion}

\subsection{Descriptive Statistics Test}

Table 1. Descriptive Statistics

\begin{tabular}{|c|c|c|c|c|c|}
\hline \multicolumn{6}{|c|}{ Descriptive Statistics } \\
\hline & $\mathbf{N}$ & Minimum & Maximum & Mean & Std. Deviation \\
\hline $\begin{array}{l}\text { Economic } \\
\text { Growth }\end{array}$ & 147 & 503646211 & 20494100000000 & 679938470876 & 2592353477101 \\
\hline $\begin{array}{l}\text { Foreign Direct } \\
\text { Investment }\end{array}$ & 147 & -239270000000 & 258390000000 & 7535639680 & 39634762869 \\
\hline
\end{tabular}




\begin{tabular}{lc|l|l|l|l}
\hline $\begin{array}{l}\text { Educational } \\
\text { Rate }\end{array}$ & 147 & 38,26865 & 99.93000 & 79.2543192 & 19.51286196 \\
\hline $\begin{array}{l}\text { Valid N } \\
\text { (listwise) }\end{array}$ & 147 & & & & \\
\hline
\end{tabular}

Source: Data Processing

Table 1 show that the economic growth variable has an average value of 679938470876 . This figure represents the average economic growth of the 147 samples used. The economic growth variable has a minimum value of 503646211 owned by the Dominica country, one of the smallest countries in the world with low GDP and not many reliable sectors, and a maximum value of 20494100000000 owned by the United States, superpower in all sectors with a very significant GDP in the world.

The Foreign Direct Investment variable has an average value of 7535639680 , with a minimum value of -239270000000 owned by the Netherlands, maybe it can be related to the government's low commitment or the long-term realization of foreign investment plans, and a maximum value of 25839 billion owned by the United States, one of the reasons could be because America has long had many large companies and multinational brands.

The educational rate variable has an average value of 79.2543192 , with a minimum value of 38.26865 owned by the South Sudan state, one of the countries experiencing malnutrition crisis which will have an impact on education, and a maximum value of 99.93000 owned by the San Marino state, one of the smallest countries but has a good education systems and standards.

Table 2. Frequencies

\begin{tabular}{llr|r|r|r}
\hline \multicolumn{7}{c}{ IFRS } \\
\hline & & & & \multicolumn{2}{c}{$\begin{array}{c}\text { Cumulative } \\
\text { Percent }\end{array}$} \\
\hline \multirow{2}{*}{ Valid } & Frequency & Percent & Valid Percent & \multicolumn{2}{c}{ Per.7 } \\
\cline { 2 - 7 } & 0 & 98 & 66.7 & 66.7 & 100.0 \\
\cline { 2 - 7 } & 1 & 49 & 33.3 & 33.3 & \\
\cline { 2 - 7 } & Total & 147 & 100.0 & 100.0 & \\
\hline Source: & Data Processing & & & &
\end{tabular}

Source: Data Processing

The IFRS variable is a variable with a dummy scale, where 0 is the sample that has not fully adopted IFRS, while 1 represents countries that have fully adopted IFRS. Table 2 shows that 98 out of 147 samples or $66.7 \%$ of countries have not fully adopted IFRS, while 49 of 147 samples or $33.3 \%$ of countries have fully adopted IFRS. 
4.2 Logistic Regression Analysis Test

1) Overall Model Fit

Table 3. Overall Model Fit

\begin{tabular}{|c|c|c|c|c|c|}
\hline & It & ration & istory a, & o, c, d & \\
\hline & & & Coe & fficients & \\
\hline Iterati & $\begin{array}{c}-2 \log \\
\text { likelihood }\end{array}$ & Constant & $\begin{array}{c}\text { Economic } \\
\text { Growth }\end{array}$ & $\begin{array}{c}\text { Foreign Direct } \\
\text { Investment }\end{array}$ & $\begin{array}{c}\text { Educational } \\
\text { Rate }\end{array}$ \\
\hline Step & 182,385 &,- 317 &, 000 &, 000 &,- 004 \\
\hline 1 & 179,325 &,- 301 &, 000 &, 000 &,- 004 \\
\hline & 175,994 &,- 214 &, 000 &, 000 &,- 004 \\
\hline & 174,591 &,- 138 &, 000 &, 000 &,- 004 \\
\hline 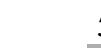 & 174,450 &,- 129 &, 000 &, 000 &,- 004 \\
\hline r & 174,448 &,- 128 &, 000 &, 000 &,- 004 \\
\hline
\end{tabular}

a. Method: Enter

b. Constant is included in the model.

c. Initial -2 Log Likelihood: 187.135

d. Estimation terminated at iteration number 6 because parameter estimates changed by less than, 001 .

Source: Data Processing

Table 3 shows that a decline in the value of -2 Log Likelihood beginning at 187,135 to 174.448 at the end of the value -2 Log Likelihood. The decrease in the Log Likelihood value indicates that the regression model used is declared good or the hypothesized model is fit with the data.

2) Determination Coefficient Test (Nagelkerke R Square)

Table 4. Determination Coefficient Test

\begin{tabular}{lc|r|r}
\hline \multicolumn{4}{c}{ Model Summary } \\
\hline Step & $\begin{array}{c}\mathbf{- 2} \text { Log } \\
\text { likelihood }\end{array}$ & $\begin{array}{c}\text { Cox \& Snell } \\
\text { R Square }\end{array}$ & $\begin{array}{c}\text { Nagelkerke } \\
\text { R Square }\end{array}$ \\
\hline 1 & $174,487^{\text {a }}$ &, 446 &, 537 \\
\hline
\end{tabular}

a. Estimation terminated at iteration number 7 because

parameter estimates changed by less than, 001.

Source: Data Processing 
Table 4 shows that the Nagelkerke R Square value is 0,537 or $53.7 \%$. The result that can be concluded is that the variability of the independent variables in the form of economic growth, foreign direct investment, and educational rate is able to explain the variability of the dependent variable by $53.7 \%$, while the remaining $46.3 \%$ is explained by other variables outside of this study.

3) Regression Model Feasibility Test

Table 5. Determination Coefficient Test

\begin{tabular}{l|l|l|l}
\hline \multicolumn{4}{|c}{ Hosmer and Lemeshow Test } \\
\hline Step & Chi-square & df & Sig. \\
\hline 1 & 5,197 & 8 &, 736 \\
\hline \multicolumn{3}{r}{ Source: Data Processing } \\
\hline
\end{tabular}

Table 5 shows that the chi-square value is 5.197 with a significance level of 0.736 . Significance value of 0, 736 far exceeds the criteria Hosmer and Lemesgow's Goodness of Fit is 0.05 . These results indicate that the observed value can be predicted by regression models or acceptable models.

4) Classification Matrix Test

Table 6. Classification Table

\begin{tabular}{|c|c|c|c|c|c|}
\hline \multicolumn{6}{|c|}{ Classification Table ${ }^{\text {a }}$} \\
\hline & & & \multicolumn{3}{|c|}{ Predicted } \\
\hline \multicolumn{3}{|c|}{ Observed } & \multicolumn{2}{|c|}{ IFRS } & \multirow{2}{*}{$\begin{array}{c}\text { Percentage } \\
\text { Correct }\end{array}$} \\
\hline & & & 0 & 1 & \\
\hline \multirow[t]{3}{*}{ Step 1} & IFRS & 0 & 97 & 1 & 99.0 \\
\hline & & 1 & 4 & 45 & 91.8 \\
\hline & Overa & ce & & & 95.4 \\
\hline
\end{tabular}

a. The cut value is, 500

Source: Data Processing

Table 6 shows the predictive power of the regression model for predicting a sample that fully implements IFRS. The samples that did not fully adopt IFRS were 98 samples. The prediction results obtained were that 97 samples did not fully adopt IFRS, while the remaining 1 sample had fully adopted IFRS. These results indicate that there are 97 correct predictions or the accuracy of the prediction is $99 \%$.

The samples that have fully adopted IFRS are 49 samples. The results obtained are 45 countries have fully adopted IFRS, while the remaining 4 samples have not fully adopted IFRS. These results indicate that there are 45 correct predictions or the accuracy of the predictions is $91.8 \%$. The overall prediction accuracy (overall percentage) in this regression model is $95.4 \%$. 
Table 7. Logistic Regression Test Results

\section{Variables in the Equation}

\begin{tabular}{llc|c|c|c|c|c} 
& & B & SE & Wald & df & Sig. & Exp (B) \\
\hline Step 1 a & Economic Growth &, 000 &, 000 & 5,179 & 1 &, 023 & 1,000 \\
\cline { 2 - 8 } & $\begin{array}{l}\text { Foreign Direct } \\
\text { Investment }\end{array}$ &, 000 &, 000 & 2,358 & 1 &, 125 & 1,000 \\
\cline { 2 - 8 } & Educational Rate &,- 004 &, 009 &, 162 & 1 &, 688 &, 996 \\
\hline Constant &,- 128 &, 766 &, 028 & 1 &, 867 &, 880 \\
\hline
\end{tabular}

Data processing

The regression equation obtained based on table 6 is as follows:

$$
\operatorname{Ln} \frac{\mathrm{P}}{1-\mathrm{P}}=-0,128-0,004 \mathrm{ER}+0,000 \mathrm{FDI}-0,000 \mathrm{ZEG}+\varepsilon
$$

1) Effect of Economic Growth on IFRS Implementation

Table 7 shows that Economic Growth has a coefficient of $0.000 \mathrm{~d}$ with a significance level of 0.023 or $<0.05$. These results indicate that Economic Growth has a positive and significant effect on IFRS implementation, which means H1 is accepted. If country's economic growth is high, economic activity, industry and trade will also go up. So that the accounting system needs to be customized and promote the decision making in fully adopting IFRS. This is the same as previous research in this article.

2) The Influence of Foreign Direct Investment on IFRS Implementation

Table 7 shows that Foreign Direct Investment has a coefficient of $0.000 \mathrm{~d}$ with a significance level of 0.125 or $>0.05$. These results indicate that Foreign Direct Investment has no effect on IFRS implementation, which means that $\mathrm{H} 2$ is rejected. There may be other factors affecting IFRS which are not covered in the model. This is the same as previous research in this article.

3) Effect of Educational Rate on IFRS Implementation

Table 7 points that the Educational Rate coefficient - 0,004 with a significance level of 0.688 or $>0.05$. These results indicate that Educational Rate has no effect on IFRS implementation, which means that $\mathrm{H} 3$ is rejected. There may be other factors affecting IFRS which are not found in the model. This is the same as previous research in this article.

\section{Conclusion}

Economic Growth has a positive and significant effect on IFRS implementation, which means that the better a country's economy will promote companies in implementing IFRS.

Foreign Direct Investment has no effect on IFRS implementation, which means that the size of a country's investment does not encourage the country to implement IFRS. 
Educational Rate has no effect on IFRS implementation, which means that the average level of education of the population of a country does not encourage the country to implement IFRS.

\section{References}

[1] A. V. Fitriana, "Factors that Influence Countries in Fully Adopting International Financial Reporting Standards (IFRS)," vol. 307, no. SoRes 2018, pp. 86-88, 2019.

[2] C. Zehri, "Does adoption of international accounting standards promote economic growth in developing countries? Asma ABDELBAKI Researcher in the Higher Institute of Management of Gabes-Tunisia," Int. Open J. Econ., vol. 1, no. 1, pp. 1-13, 2013.

[3] D. Zeghal and K. Mhedhbi, "An analysis of the factors affecting the adoption of international accounting standards by developing countries," Int. J. Account., vol. 41, no. 4, pp. 373-386, 2006.

[4] J. J. Weygandt, D. E. Kieso, and P. D. Kimmel, Principles of financial accounting. Jerry J. Weygandt, Donald E. Kieso, Paul D. Kimmel. 2015.

[5] J. . Reeve, C. . Warren, and J. . Duchac, Principle of Accounting. 2014.

[6] L. Rahmawati and H. Murtini, "Kualitas Informasi Akuntansi Pra Dan Pasca Adopsi Ifrs," Account. Anal. J., vol. 4, no. 2, pp. 1-9, 2015.

[7] S. M. Sheffrin, Economics: Principles, Applications, and Tools, Global Edition, 9/e. 2018.

[8] J. Gerber, International Economics, Global Edition, 7e. 2017.

[9] G. Alzaidy, M. Naseem, B. Niaz, and Z. Lacheheb, "The Impact of Foreign-direct Investment on Economic Growth in Malaysia: The Role of Financial Development," Int. J. Econ. Financ. Issues, vol. 7, no. 3, pp. 382-388, 2017.

[10] K. M. Shima and D. C. Yang, "Factors affecting the adoption of IFRS," Int. J. Bus., 2012. 